\title{
The Kveim test in Crohn's disease*
}

\author{
D. N. Mitchell \\ Medical Research Council, \\ Tuberculosis and Chest Diseases Unit, \\ Brompton Hospital, London \\ N. C. DYER ${ }^{2}$ \\ Medical Registrar, \\ Gastro-enterology Unit, \\ St Bartholomew's Hospital, London
}

\author{
P. CANNON ${ }^{1}$ \\ Senior Medical Registrar, \\ The London Hospital
}

K. F. W. Hinson

Director of Pathology, Brompton Hospital, London

\author{
J. M. T. WilloughBY ${ }^{3}$ \\ Research Associate, \\ Nutritional and Intestinal Unit, \\ The General Hospital, Birmingham
}

\begin{abstract}
Summary
Kveim tests were done in forty-eight patients with Crohn's disease. Of forty-five with definite or probable Crohn's disease, twenty-three had a positive Kveim test. This finding could be explained:

(1) By cross-reactivity between sarcoidosis and Crohn's disease antigens;

(2) By an aetiological agent common to the two diseases, or

(3) By a property of the Kveim test material used in testing.
\end{abstract}

Because of the close similarity between the microscopic appearance of the focal granulomas seen in Crohn's disease and those of sarcoidosis, patients with Crohn's disease were included in a study of the specificity of the Kveim test. This paper summarizes the preliminary findings.

\section{Patients}

The aim was to make Kveim tests in patients with active or recently active Crohn's disease who had not previously had steroids and who were unlikely to receive treatment with steroids during the period (4-6 weeks) required for completion of the Kveim test. So far, a total of forty-eight patients have been tested. In twenty-four the diagnosis was established histologically, and in a further fourteen a firm

Present addresses: ${ }^{1}$ Consultant Physician, Harold Wood Hospital, Harold Wood, Essex. ${ }^{2}$ Senior Medical Registrar, Queen Elizabeth Hospital, Birmingham. ${ }^{3}$ Honorary Lecturer in Medicine, St Bartholomew's Hospital, London. clinical diagnosis had been reached. In the remaining ten the diagnosis was considered probable or doubtful. In the event, six patients received steroids during the period of Kveim testing, namely, four with histologically confirmed disease, one with clinically definite and one with doubtful disease.

\section{Materials and methods}

The Kveim test material was derived from a single lot (lot 5) of carefully validated Type 1 (ChaseSiltzbach) sarcoid spleen (K 12) test suspension. The Kveim tests were given intracutaneously $(0.15 \mathrm{ml})$ on the ulnar aspect of the left forearm and were identified by a single tattoo speck of autoclaved Gunter-Wagner 'Pelikan' ink. This marker could subsequently be seen at the edge of any visible or palpable reaction at the test site and it was always included within the area of a full-thickness skin punch biopsy $(4 \mathrm{~mm})$ which was performed in all patients after an interval of 4-6 weeks following injection. The maximum diameter of any induration or papule at the Kveim test sites was measured with calipers and recorded in millimetres immediately prior to the biopsy. Serial sections of each biopsy were prepared and read 'blind' by two observers (K.W.H. and D.N.M.) independently. The microscopic readings were recorded as 'positive', 'equivocal' or 'negative' according to the criteria of Siltzbach \& Ehrlich (1954). When possible, simultaneous intracutaneous tests were made on the

*This paper has appeared in the Lancet (1969, ii, 571-573) and is reproduced by kind permission of the Editor. 
TABLE 1. The Kveim test in Crohn's disease, results of microscopic reading of Kveim test biopsies

\begin{tabular}{|c|c|c|c|c|c|c|c|c|}
\hline \multirow{3}{*}{ Diagnosis } & \multirow[b]{3}{*}{ Number } & \multicolumn{3}{|c|}{ All patients } & \multicolumn{4}{|c|}{$\begin{array}{l}\text { Patients having previously } \\
\text { had bowel resection }\end{array}$} \\
\hline & & \multicolumn{3}{|c|}{ Kveim test result } & \multirow[b]{2}{*}{ Number } & \multicolumn{3}{|c|}{ Kveim test result } \\
\hline & & Positive & Equivocal & Negative & & Positive & Equivocal & Negative \\
\hline $\begin{array}{l}\text { Definite Crohn's disease } \\
\text { with histological } \\
\text { confirmation }\end{array}$ & 24 & $\begin{array}{c}10 \dagger(42 \%) \\
\text { (1) }\end{array}$ & $3 *(1)$ & $11 *(2)$ & 17 & $7(41 \%)$ & 3 & 7 \\
\hline $\begin{array}{l}\text { Definite Crohn's disease } \\
\text { without histological } \\
\text { confirmation }\end{array}$ & 14 & $9(64 \%)$ & 0 & $5^{*}(1)$ & 4 & 2 & 0 & 2 \\
\hline Probable Crohn's disease & 7 & 4 & 1 & 2 & 1 & 0 & 0 & 1 \\
\hline Doubtful Crohn's disease & 3 & 1 & 2 & 0 & 1 & 1 & 0 & 0 \\
\hline Total patients & 48 & $24(50 \%)$ & $6(12 \%)$ & $18(37 \%)$ & 23 & $10(43 \%)$ & $3(13 \%)$ & $10(43 \%)$ \\
\hline
\end{tabular}

* Including the number of patients, in parentheses, receiving steroids during the period of Kveim testing.

right forearm using tuberculin (10 TU and, if negative, 100 TU P.P.D.) and with a heat-killed Candida albicans suspension $(0.1 \mathrm{ml}$ of a 1:1000 dilution); these results will be reported later.

\section{Results}

The microscopic readings of the Kveim test (by K.W.H.- who, at the time, was unaware of the origin of the subjects tested and of the nature or identity of the test suspension) are set out in Table 1 . K.W.H. later made a further assessment, this time knowing that the tests had been made with a single lot of validated Kveim test suspension (K 12, lot 5) in subjects with definite, probable or doubtful Crohn's disease; his readings were unchanged. Moreover, this assessor confirmed that the positive microscopic appearances were typical of the Kveim reaction in sarcoidosis (Figs. 1 and 2), and he was unable to identify any unusual or atypical microscopic characteristics. The readings of the second assessor D.N.M. were closely similar to those of K.W.H.

Of the total of forty-eight patients, twenty-four $(50 \%)$ had microscopically positive Kveim tests. Among the twenty-four patients in whom the diagnosis of Crohn's disease was histologically confirmed, ten $(42 \%)$ were Kveim positive, and among the fourteen in whom the diagnosis was clinically but not histologically confirmed nine $(64 \%)$ were positive. The difference in percentage Kveimpositive in these two groups is not statistically significant. The results in patients who had previously had bowel resection were closely similar to those who had not.

\section{Discussion}

The Kveim test material used in the present study was derived from a single lot of a spleen which has been established as potent for sarcoidosis in a double-blind evaluation (Mitchell, Sutherland \& Bradstreet, 1969). In this standardization study, fourteen $(70 \%)$ of twenty patients with definite active sarcoidosis and two of twelve patients with definite inactive sarcoidosis at the time of testing gave a positive reaction. In contrast, only two positive reactions were obtained in sixty-three patients without sarcoidosis (active and quiescent pulmonary tuberculosis and apparently healthy subjects), namely, one in a patient with quiescent pulmonary tuberculosis and one in an apparently healthy subject.

A few patients with Crohn's disease have been given Kveim tests as part of an evaluation of the test as a diagnostic measure in sarcoidosis. Thus, Rogers \& Haserick (1954) tested a patient with Crohn's disease and a patient with chronic ulcerative colitis among a total of nineteen patients with diseases other than sarcoidosis. These tests were made intracutaneously and biopsy of the test site 6 weeks later was microscopically negative. Similarly, Siltzbach (1961) found only one positive Kveim result among sixty-three patients with tuberculosis and one (a patient with Hamman-Rich syndrome) among 240 patients with a wide variety of other diseases (rheumatoid arthritis, Hodgkin's disease, regional enteritis, Hamman-Rich syndrome, liver cirrhosis, connective tissue disorders, malignancy, diabetes and hypertensive heart disease).

The only previous study of the Kveim test specifically in Crohn's disease showed uniformly 


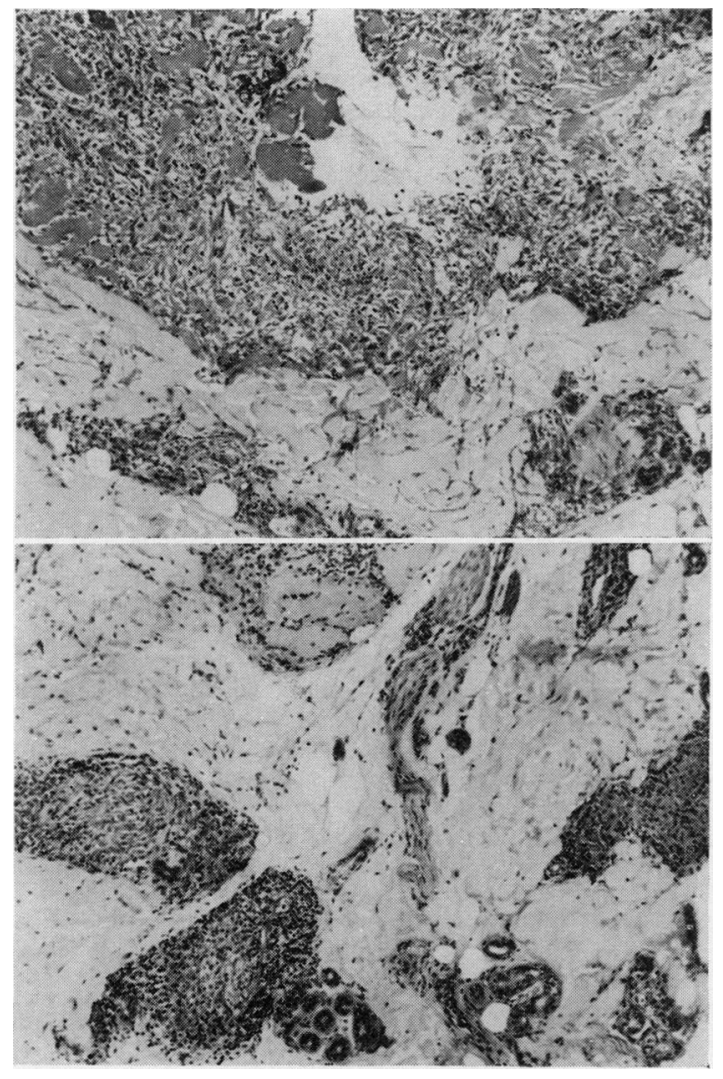

FIgs. 1 and 2. Microscopic appearances of positive Kveim reactions in each of two patients having definite Crohn's disease with histological confirmation. Fig. 1 (upper) showing several epitheloid cell granulomata in the deeper dermis; Fig. 2 (lower) showing epitheloid cell granulomata with tissue necrosis (stained $\mathrm{H} \& \mathrm{E} \times 65$ ).

negative results (Jones Williams, 1965 and 1969). Although Jones Williams (1965) used an antigen prepared from the same spleen (K 12) as that of the present study, he injected a somewhat smaller test dose $(0.1 \mathrm{ml})$ and did so into the superficial subcutaneous tissue on the forearm (the site being marked). The Kveim test sites were inspected carefully at $48 \mathrm{hr}$, and at 2, 4 and 6 weeks following injection, but no visible papules were noted; no biopsy of any of the test sites was made. However, Siltzbach \& Ehrlich (1954) state that biopsy of all test sites is essential for a reliable assessment of the Kveim test; they occasionally found that apparently nonreactive sites contained unequivocal granulomas on microscopic examination (conversely, but more rarely, a papule of $2 \mathrm{~mm}$ or more in diameter failed to show a granuloma when examined microscopically).

In the present study, in which the Kveim test material was injected intracutaneously, a papule was frequently present at the test site and biopsy of all test sites was made after an interval of 4-6 weeks after injection. Many of the patients with Crohn's disease in the present study showed only a small papule or even a tiny area of induration at the Kveim test site (the full details will be reported later). The routine technique of marking the test site was of value, as without it, some microscopically positive reactions might have been missed (Siltzbach, personal communication; Mitchell, 1968a). The positive Kveim results in the present series of patients with Crohn's disease showed characteristic granulomata which could not be differentiated microscopically from the positive results with the same suspension in patients with sarcoidosis. Williams \& Nickerson (1935), using a sterile particulate saline suspension prepared from a sarcoid skin lesion, reported the appearance of a firm red papule at the test site in four patients with histologically proven sarcoidosis. No such reactions were observed in four control subjects. Although the papules were examined for 1 week only after injection, and biopsies were not made, the findings are of interest since two of the patients had undergone extensive bowel resection, the histology showing changes compatible with sarcoidosis. It is therefore possible that there are two patients had Crohn's disease rather than sarcoidosis.

It is of interest to consider possible explanations for this finding. It may be that if patients with active or recently active Crohn's disease are tested with other validated Kveim suspensions of proven potency for sarcoidosis a substantial proportion will also show a positive Kveim test. This would suggest that patients with sarcoidosis or Crohn's disease are exposed to a similar or identical antigen and that a cross reactivity can then be demonstrated by means of the Kveim test. Alternatively, a common aetiological agent for the two diseases may exist. It is also possible that the positive findings may be limited to tests made with suspensions from the particular spleen (K 12) used in this study, or indeed to the particular lot of test material (lot 5) which we used. Kveim tests with a validated suspension from another spleen are currently being made to investigate these possibilities.

If positive Kveim reactions result from a cross reactivity of response to a validated test material in Crohn's disease, the same may hold for other conditions or in other circumstances. It is of interest that positive Kveim tests have been reported among patients with tuberculoid leprosy (Kooij \& Gerritsen, 1958; Kooij, 1963; Pearson et al., 1969) and also in apparently healthy subjects who showed no evidence of sarcoidosis or other disease, and who failed to show conversion to tuberculin sensitivity following two technically satisfactory BCG vaccina- 
tions (Hart, Mitchell \& Sutherland, 1964; Mitchell et al., 1967, 1968b).

\section{Acknowledgments}

We are grateful for the cooperation of physicians and surgeons at the following hospitals: St Bartholomew's Hospital, The Central Middlesex Hospital, The General Hospital, Birmingham, St George's Hospital, The London Hospital, St Mark's Hospital, The Royal Naval Hospital, Plymouth, The Royal South Hants Hospital, and St Thomas's Hospital.

In particular, we wish to thank the following for allowing us to include their patients in this study: Dr F. Avery Jones, Dr R. R. Bomford, Professor B. N. Brooke, Dr W. T. Cooke, Dr A. M. Dawson, Dr M. Floyer, Mr J. D. Griffiths, Dr T. D. Kellock, Dr Evan Jones, Dr J. E. Lennard Jones, Mr C. V. Mann, Mr I. McColl, The Medical Officer in Charge, R.N.H., Plymouth, Dr N. Oswald, Mr A. G. Parks, Mr R. Purvis, Professor H. D. Ritchie, Mr Hermon Taylor, Mr I. P. Todd, Dr J. T. Wright. Dr Patricia Bradstreet (Director, Standards Laboratory for Serological Reagents, Public Health Laboratory Service, Colindale) kindly prepared the Kveim test suspension.

We wish to thank Dr G. L. Asherson, Dr P. D'Arcy Hart, Dr Wallace Fox, Dr R. J. W. Rees and Dr I. Sutherland for their constructive comments and advice.

\section{References}

Hart, P. D'Arcy, Mitchell, D.N. \& Sutherland, I. (1964) Associations between Kveim test results, previous B.C.G. vaccination, and tuberculin sensitivity in healthy young adults. British Medical Journal, 1, 795.

JoNes Williams, W. (1965) A study of the Crohn's syndrome using tissue extracts and the Kveim and Mantoux tests. Gut, 6, 503-5.
Jones Williams, W. (1969) Crohn's disease. The Practitioner, 202, 643-9.

KoOIJ, R. \& Gerritsen, T. (1958) The nature of the mitsuda and the Kveim reaction. Dermatologica, 116, 1 .

Kools, R. (1963) The Nature of the Kveim Reaction. Acta Medica Scandinavica, suppl. no. 425, 79.

Mitchell, D.N., Siltzbach, L.E., Sutherland, I. \& Hart P. D'ARCY (1967) Some further observations on the Kveim test in relation to BCG vaccination and tuberculin sensitivity. La Sarcoidose. Rapports de la IV Conférence internationale, p. 154. Masson et Cie, Paris.

Mitchell, D.N. (1968) The Kveim test. Recent Advances in Clinical Pathology. (Ed. Dyke), p. 431, Churchill, London.

Mitchell, D.N., Siltzbach, L.E., Sutherland, I. \& Hart, P. D'Arcy (1968b) Immunologic deficiency diseases in man. British Defects. Original article series vol. IV No. 1, p. 365.

Mitchell, D.N., Sutherland, I. \& Bradstreet, C.M.P. (1970) Validation and standardisation of Kveim test suspensions prepared from human sarcoid spleen. Fifth International Conference on Sarcoidosis, Prague. (In press.)

Pearson, J.M.H., Pettit, J.M.S., Siltzbach, L.E., Ridley, L.S., HART, P. D'ARCY \& ReEs, R.J.W. (1969) The Kveim test in lepromatous and tuberculoid leprosy. International Journal of Leprosy, 37,

Rogers, F.J. \& HASERICK, J.R. (1954) Value of the Kveim test as a diagnostic measure in sarcoidosis. A Preliminary Report. Cleveland Clinic Quarterly, 21, 79-89.

SiltzbaCh, L.E. \& Ehrlich, J.C (1954) The NickersonKveim reaction in sarcoidosis. American Journal of Medicine, 16, 726-30.

SiltzBaCH, L.E. (1961) The Kveim test in sarcoidosis; a study of 750 patients. Journal of the American Medical Association, 178, 476-82.

Williams, R.H. \& Nickerson, D.A. (1935) Proceedings of the Society for Experimental Biology and Medicine, 33, 403. 